\title{
The effect of cell type on surgico-pathologic risk factors in endometrial cancer
}

\section{Endometrium kanserinde hücre tipinin cerrahi-patolojik risk faktörlerine etkisi}

\author{
Ahmet Taner Turan ${ }^{1}$, Betül Dündar ${ }^{1}$, Burcu Gündoğdu ${ }^{1}$, Abdullah Boztosun$^{2}$, Nejat Özgül ${ }^{1}$, Nurettin Boran $^{1}$, \\ Gökhan Tulunay ${ }^{1}$, Ahmet Özfuttu ${ }^{3}$, Mehmet Faruk Köse ${ }^{1}$ \\ 'Department of Gynecologic Oncology, Etlik Zübeyde Hanım Women, Ankara, Turkey \\ ${ }^{2}$ Department of Gynecology and Obstetrics, Cumhuriyet University, Sivas, Turkey \\ ${ }^{3}$ Department of Pathology, Etlik Zübeyde Hanim Women, Ankara, Turkey
}

\section{Abstract}

Objective: In this study the effect of histologic subtype as a surgicopathologic risk factor in endometrial cancer is evaluated.

Material and Methods: We evaluated 182 patients who underwent systematic lymphadenectomy up to the level of the renal vessels and at least 15 lymph nodes were dissected from the pelvic area and 10 lymph nodes from the para-aortic area. investigation of whether endometrioid and aggressive cell types (serous papillary cell and clear cell) affect the distribution of surgicopathologic risk factors among endometrial cancer cases was carried out.

Results: Patients in the aggressive cell type group were older and the tumor size was significantly smaller. There was no difference between the two groups for the total number of dissected lymph nodes except for the external iliac area. Although the difference is not statistically significant, the total number of lymph nodes dissected in the aggressive group was less ( 54.3 vs $62.9, \mathrm{p}=0.067$ ) than that of the endometrioid cell type group. While the incidence of pelvic lymph node metastasis in the aggressive group was $59.1 \%$ the incidence was $15.6 \%$ in the endometrioid cell type group ( $\mathrm{p}>0.001)$. The possibility of lymph node metastasis for aggressive cell type endometrial carcinoma in the para-aortic area was twice the endometrioid cell type group. It was found that the presence and type (stromal/glandular) of cervical invasion, depth of myometrial invasion and presence of lymphovascular space invasion were not affected by cell type.

Conclusion: Aggressive cell types significantly increase the adnexial and lymph node metastasis in endometrial cancer.

(J Turkish-German Gynecol Assoc 2011; 12: 9-14)

Key words: Endometrial carcinoma, cell type

Received: 12 December, 2010

Accepted: 19 February, 2011

\section{Introduction}

Endometrial cancer is the fourth most common cancer among women worldwide (1). More than $80 \%$ of the cases are endometrioid type histologically and are associated with a good prognosis (2). Clear cell and serous papillary cell carcinoma, which are the aggressive ones, are quite rare, with an incidence of $1-6 \%$ and $1-10 \%$, respectively (3-6).

Serous papillary cell carcinoma of the uterus resembles epithelial ovarian cancer with its aggressive clinical course $(7,8)$.

\section{Özet}

Amaç: Bu çalışmada endometrium kanserinde hücre tipinin cerrahipatolojik risk faktörleri üzerine olan etkisi araştırıldı.

Gereç ve Yöntemler: Endometrium kanseri nedeniyle renal damarlar seviyesine kadar sistematik lenf nodu diseksiyonu yapılan 182 hasta retrospektif olarak değerlendirildi. Lenf nodu diseksiyonu yapılan olgularda pelvik bölgeden en az 15 adet, para-aortic bölgeden de en az 10 adet lenf nodu çıkarılmıştır. Hastalar yapılan histolojik değerlendirme sonucuna göre hücre tipine göre endometrioid hücre tipi ve agresif hücre tipi (seröz papiller ve berrak hücreli) olmak üzere 2 gruba ayrıldı.Bu iki grup cerrahi-patolojik risk faktörlerinin dağılımı açısından karşılaştırıldı.

Bulgular: Agresif hücre tipi grubunda yer alan hastaların yaş ortalaması daha yüksekti ve tümör boyutu daha küçüktü. İki grup arasında eksternal iliak bölge dışında diseke edilen lenf nodu sayısı açısından fark olmadığı bulundu. Agresif hücre tipi grubunda çıkarılan toplam lenf nodu sayısı endometrioid hücre tipi grubundan daha azdı fakat fark istatistiksel olarak anlamlı değildi ( 54.3 vs $62.9, \mathrm{p}=0.067$ ). Agresif hücre tipi grubunda pelvik lenf nodu metastazı insidansı \%59.1 iken endometrioid hücre tipi grubunda insidans \%15.6 olarak bulundu ( $p>0.001)$. agresif hücre tipi grubunda para-aortic lenf nodu metastazı olasılığının diğer grubun 2 katı olduğu görüldü. Servikal invazyon ve invazyonun tipinin (stromal/glandüler), miyometrial invazyonun derinliğinin ve lenfovasküler alan invazyonunun hücre tipinden etkilenmediği görüldü.

Sonuç: Endometrium kanserinde agresif hücre tipi adneksiyal alan ve lenf nodu metastazını istatistiksel olarak anlamlı ölçüde arttırmaktadır. (J Turkish-German Gynecol Assoc 2011; 12: 9-14)

Anahtar kelimeler: Endometrium kanseri, hücre tipi

Geliş Tarihi: 12 Aralık 2010

Kabul Tarihi: 19 Şubat 2011

Clear cell carcinoma of the uterus is another aggressive type of endometrial cancer, which has a similar relapse pattern to uterine serous papillary cell carcinoma and a 5 year survival less than $50 \%(3,9)$. In addition to serous papillary cell and clear cell carcinoma, there is another group with aggressive characteristics called mixed type and is histologically composed of more than $75 \%$ serous papillary or clear cells (9). Even if the tumor is only confined to the uterus in the case of an aggressive cell type, adjuvant therapies following surgery are generally recommended (10-13). Because of their aggres- 
sive clinical course radical surgical procedures are suggested, and to prevent and control the potential pelvic and extrapelvic disease, radiotherapy and/or systemic chemotherapy are recommended as adjuvant therapies.

Carighead et al. analyzed 103 patients whose histopathologic diagnosis was one of the aggressive variants of endometrial cancer and showed that pelvic radiotherapy reduces pelvic recurrence significantly and increases the overall survival in stage IB, IC, II and III cases (14).

However, in view of the fact that studies on this subject and the number of subjects included in those studies are not sufficient, the most appropriate treatment regimen for clear cell and serous papillary cell carcinoma is still controversial. For this reason, further prospective randomized trials are required to determine the most appropriate treatment method $(15,16)$. In addition, it is not clearly known that there is a relationship between the aggressive clinical course of the serous papillary and the clear cell carcinoma and the surgico-pathologic risk factors associated with those cell types.However, it is known that extra uterine spread is common among aggressive cell types $(7,13,14,17,18)$.

In this study we evaluated whether there is an association between the surgico-pathologic risk factors and cell type in endometrial cancer.

\section{Material and Methods}

Between 1993 and 2009, a total of 182 patients who had open systematic pelvic and para-aortic lymphadenectomy surgery extending to the renal vessels for endometrial cancer at the gynecologic oncology department were studied retrospectively. Patients who had no other malignancies diagnosed within two years before or after their diagnosis and who had had at least 15 lymph nodes removed from pelvic region and at least 10 lymph nodes removed from para-aortic region were included. All surgical procedures were performed by experienced gynecologic oncologists and frozen sections were studied routinely for all cases, providing information on the grade of neoplasia, histology, depth of myometrial invasion, tumor diameter, sites of extrauterine spread and lymphovascular invasion.

Patients were staged according to FIGO 1988 criteria. In addition to total abdominal hysterectomy and bilateral salphingooophorectomy, bilateral pelvic and para-aortic lymph node dissections were performed when one of the following criteria was determined by frozen section examination; (1) Grade 2-3, (2) $\geq 1 / 2$ myometrial invasion, (3) tumor size $>2 \mathrm{~cm}$, (4) adnexial metastasis, (5) cervical involvement and (6) aggressive cell types (clear cell, adenosquamous or serous papillary).

The variations in distribution of surgico-pathologic risk factors according to endometrioid cell type and other aggressive cell types were investigated.

Statistical analyses were performed using 17.0 SPSS programme. $\chi^{2}$ test and Annova Table tests are used, and $\mathrm{p}<0.05$ value is accepted as statistically significant. The study was approved by the Ethical committee in our hospital.

\section{Results}

In this study 182 patients with stage IA-IVB endometrial cancer were evaluated. The mean age was 57.3 (35-92). The mean tumor size was $40.6 \mathrm{~mm}$ with a maximum of $130 \mathrm{~mm}$. There was no tumor in nine patients. The histological subtype was endometrioid in $87.9 \%$ of patients. Grade 1 tumor was detected in 61 patients, grade 2 in 68 and grade 3 in 53. There was no myometrial invasion in 14 patients, <1/2 myometrial invasion in $68, \geq 1 / 2$ myometrial invasion in 93 and serosal infiltration was present in 11. Ovarian involvement was detected in 22 patients and tubal involvement in 13 patients. In 139 patients the information about lymphovascular space invasion (LVSI) was indicated by the histopathological examination and LVSI was determined in 57 of these patients (Table 1).

The mean of the total number of lymph nodes removed was 61.9 and 42.3 of those were dissected from the pelvic area while 19.6 e were from the para-aortic area.

Lymph node metastasis was found in 43 patients (23.6\%). Tumor spread to the pelvic lymph nodes in 38 patients (20.9\%) and to the para-aortic lymph nodes in 24 patients (13.2\%). Obturator lymph nodes were the most commonly involved area. Details of the surgico-pathologic factors of the patients are shown in Table 1.

The patients in the aggressive cell type group were older and the tumor size in this group was significantly smaller (Table 2). There was no difference between the two groups with regard to the total number of removed lymph nodes except for the external iliac area (Table 2). In the aggressive cell type group, lymph nodes dissected from the external iliac area were significantly fewer in number. Although the difference is not significant statistically, the total number of lymph nodes removed in the aggressive cell type group was also fewer (54.3 vs 62.9, $\mathrm{p}=0.067$ ). However in the aggressive cell type group, pelvic lymph node involvement was greater ( $59.1 \%$ vs $15.6 \%, \mathrm{p}<0.001$ ) (Table 3 ). The possibility of para-aortic lymph node involvement in the aggressive cell type group was twice that in the endometrioid cell type group ( $22.7 \%$ vs $11.9 \%, \mathrm{p}=0.158$ ) (Table 3 ).

Spread of disease to the tuba uterina and ovaries was more common in the aggressive cell type group (Table 3 ). While the ovarian metastasis was found in $27.3 \%$ of patients in the aggressive cell type group, the rate of ovarian metastasis was $10 \%$ in the endometrioid cell type group. The rate of tubal involvement was $18.2 \%$ and $5.6 \%$, respectively.

It was found that the presence and type of cervical invasion either stromal or glandular,and depth of myometrial invasion and presence of LVSI were not affected by cell type (Table 4).

\section{Discussion}

The term clear cell carcinoma of mesonephric origin was first described by Schiller et al. in 1939 to describe clear cell carcinoma of ovarian cancer resembling renal cell carcinoma histologically (19). The descriptive term clear cell carcinoma for tumors originating from the Müllerian duct was first introduced in 1967 by Scully and Barlow (20). The prognostic significance of clear cell histology was recognized in 1970s. Scully and 
Table 1. General parameters

\begin{tabular}{|c|c|c|c|}
\hline \multicolumn{2}{|l|}{ Parameter } & Mean / n & Range / \% \\
\hline \multicolumn{2}{|l|}{ Age (years) } & 57.3 & $35-92$ \\
\hline \multicolumn{2}{|l|}{ Tumor size $(\mathrm{mm})$} & 40.6 & $0-130$ \\
\hline \multirow{10}{*}{ Stage } & IA & 12 & 6.6 \\
\hline & IB & 48 & 26.4 \\
\hline & IC & 49 & 26.9 \\
\hline & IIA & 4 & 2.2 \\
\hline & IIB & 11 & 6 \\
\hline & IIIA & 9 & 4.9 \\
\hline & IIIB & 2 & 1.1 \\
\hline & IIIC & 45 & 24.7 \\
\hline & IVA & 1 & 0.5 \\
\hline & IVB & 1 & 0.5 \\
\hline \multirow{3}{*}{ Cell type } & Endometrioid & 160 & 87.9 \\
\hline & Clear & 11 & 6 \\
\hline & Serous papillary & 11 & 6 \\
\hline \multirow{3}{*}{ Grade } & 1 & 61 & 33.5 \\
\hline & 2 & 68 & 37.4 \\
\hline & 3 & 53 & 29.1 \\
\hline \multirow{4}{*}{ Depth of myometrial invasion } & Only endometrium & 14 & 7.7 \\
\hline & $<1 / 2$ & 68 & 37.4 \\
\hline & $\geq 1 / 2$ & 93 & 51.1 \\
\hline & Serousal infiltration & 7 & 3.8 \\
\hline \multirow[t]{2}{*}{ Peritoneal cytology } & Negative & 171 & 94 \\
\hline & Positive & 11 & 6 \\
\hline \multirow{2}{*}{ Ovarian metastasis } & Negative & 160 & 87.9 \\
\hline & Positive & 22 & 12.1 \\
\hline \multirow[t]{2}{*}{ Tuba uterina metastasis } & Negative & 169 & 92.9 \\
\hline & Positive & 13 & 7.1 \\
\hline \multirow[t]{3}{*}{ Cervical invasion } & Negative & 141 & 77.5 \\
\hline & Glandular & 8 & 4.4 \\
\hline & Stromal & 33 & 18.1 \\
\hline \multirow{3}{*}{ Lymphovascular space invasion } & Negative & 82 & 45.1 \\
\hline & Positive & 57 & 31.3 \\
\hline & Not reported & 43 & 23.6 \\
\hline \multicolumn{2}{|c|}{ Total number of removed lymph nodes } & 61.9 & $27-122$ \\
\hline \multicolumn{2}{|c|}{ Number of lymph nodes removed from pelvic area } & 42.3 & $16-81$ \\
\hline \multicolumn{2}{|c|}{ Number of lymph nodes removed from para-aortic area } & 19.6 & $10-49$ \\
\hline \multirow{3}{*}{ Lymph node status } & Negative & 139 & 76.4 \\
\hline & Pelvic lymph node metastasis & 43 & 23.6 \\
\hline & Para-aortic lymph node metastasis & 27 & 13.2 \\
\hline \multirow{5}{*}{ Pelvic lymph node area } & Common iliac lymph node & 16 & 8.8 \\
\hline & External iliac lymph node & 19 & 10.4 \\
\hline & Internal iliac lymph node & 16 & 8.8 \\
\hline & Obturator lymph node & 20 & 11 \\
\hline & Presacral lymph node node & 1 & 0.5 \\
\hline
\end{tabular}


Table 2. Age, tumor size and dissected lymph nodes according to cell types

\begin{tabular}{|c|c|c|c|c|c|c|c|c|c|c|c|}
\hline Cell type & & Age & $\begin{array}{c}\text { Tumor size } \\
(\mathbf{m m})\end{array}$ & $\begin{array}{l}\text { Total } \\
\text { LN }\end{array}$ & $\begin{array}{l}\text { PA } \\
\text { LN }\end{array}$ & $\begin{array}{c}\text { Total } \\
\text { pelvic LN }\end{array}$ & CI LN & EI LN & II LN & PS LN & O LN \\
\hline \multirow[t]{4}{*}{ Endometrioid } & Mean & 56.7 & 41.9 & 62.9 & 20 & 43.1 & 9.71 & 11.6 & 5.2 & 1.74 & 14.9 \\
\hline & Minimum & 35 & 0 & 27 & 10 & 16 & 2 & 2 & 0 & 0 & 0 \\
\hline & Maximum & 92 & 130 & 122 & 49 & 81 & 26 & 28 & 20 & 8 & 41 \\
\hline & Median & 56 & 40 & 58.5 & 18 & 40 & 9 & 11 & 6 & 1 & 15 \\
\hline \multirow{4}{*}{$\begin{array}{l}\text { Clear cell and } \\
\text { serous type }\end{array}$} & Mean & 62.3 & 31.7 & 54.3 & 17.4 & 37 & 8.1 & 9 & 6.5 & 1.23 & 12.2 \\
\hline & Minimum & 48 & 5 & 32 & 9 & 18 & 2 & 4 & 1 & 0 & 3 \\
\hline & Maximum & 76 & 60 & 87 & 33 & 59 & 20 & 14 & 15 & 7 & 26 \\
\hline & Median & 62.5 & 32.5 & 50.5 & 15.5 & 34.5 & 8 & 9 & 6 & 0 & 11 \\
\hline \multicolumn{2}{|l|}{$\mathrm{p}$} & 0.009 & 0.029 & 0.067 & 0.167 & 0.068 & 0.142 & 0.030 & 0.119 & 0.291 & 0.085 \\
\hline
\end{tabular}

Table 3. Lymph node, ovarian and tubal involvement according to cell type (\%)

\begin{tabular}{|l|c|c|c|c|c|c|c|c|c|}
\hline Cell type & PA LN & $\begin{array}{c}\text { Total } \\
\text { pelvic LN }\end{array}$ & CI LN & EI LN & II LN & PS LN & O LN & $\begin{array}{c}\text { Ovarian } \\
\text { involvement }\end{array}$ & $\begin{array}{c}\text { Tubal } \\
\text { involvement }\end{array}$ \\
\hline Endometrioid & 11.9 & 15.6 & 6.9 & 7.5 & 4.4 & 0 & 8.8 & 10 & 5.9 \\
\hline Clear cell and serous type & 22.7 & 59.1 & 22.7 & 31.8 & 40.9 & 4.5 & 27.3 & 27.3 & 18.2 \\
\hline p & 0.158 & $<0.001$ & 0.014 & $<0.001$ & $<0.001$ & 0.007 & 0.009 & 0.020 & 0.032 \\
\hline LN: Lymph node, PA: Para-aortic, CI: Common iliac, EI: External iliac, II: Internal iliac, PS: Presacral, O: Obturator \\
\hline
\end{tabular}

Table 4. Presence of cervical invasion, depth of myometrial invasion and lymphovascular space invasion according to cell type (\%)

\begin{tabular}{|c|c|c|c|c|c|c|c|c|c|}
\hline \multirow[t]{2}{*}{ Cell type } & \multicolumn{3}{|c|}{ Cervical invasion } & \multicolumn{4}{|c|}{ Depth of myometrial invasion } & \multicolumn{2}{|c|}{ LVSI } \\
\hline & Absent & Glanduler & Stromal & Endometrial & $<1 / 2$ & $\geq 1 / 2$ & Serozal & Negative & Positive \\
\hline Endometrioid & 79.4 & 4.4 & 16.3 & 6.9 & 37.5 & 52.5 & 3.1 & 79.4 & 20.6 \\
\hline Clear cell and serous type & 63.6 & 4.5 & 31.8 & 13.6 & 36.4 & 40.9 & 9.1 & 63.6 & 36.4 \\
\hline $\mathrm{p}$ & \multicolumn{3}{|c|}{0.201} & \multicolumn{4}{|c|}{0.327} & \multicolumn{2}{|l|}{0.098} \\
\hline
\end{tabular}

Kurman reported a series of 21 cases of clear cell carcinoma with an unfavorable clinical course (21).

The concept of uterine serous papillary carcinoma was first brought out by Hendrichson and described as a rare aggressive subtype of endometrioid adenocarcinoma (22). The main histological property of serous papillary carcinoma is the psammoma bodies and the distinct papillary microarchitecture. The serous papillary carcinoma of the uterus, which is a very different clinicopathological entity from endometrioid adenocarcinoma, also differs from the carcinogenesis point of view. The major role in the molecular pathogenesis of uterine serous papillary carcinoma is p53 inactivation (23-25). Overexpression of the p53 gene is observed in $80 \%$ of all uterine serous papillary carcinoma cases, while this rate is only $10-25 \%$ among all high grade endometrioid adenocarcinoma cases.

The biological behavior of serous papillary malignancies of other tissues, such as the ovaries and the peritoneum, resembles that of uterine serous papillary carcinoma. The reason for this is that the p53 gene inactivation is common in all types of serous papillary malignancies and all of them have the capability to develop aggressively and rapidly instead of undergoing some slow processes of tumor development depending on hormone related mechanisms $(23,25)$.

In this studywa it is found that the aggressive cell type significantly increases the pelvic lymph node involvement. Pelvic lymph node metastasis was present in $16 \%$ of the endometrioid cell type group, while this ratio was $59 \%$ among the aggressive cell type group. When the cases were investigated in detail, it was observed that lymph node involvement in all areas of the pelvis was significantly higher among clear cell and serous papillary cell types. In contrast, lymph node involvement in the para-aortic area was found to be independent of cell type.

Typically, uterine serous papillary cell carcinoma differs from the endometrioid adenocarcinoma with its aggressive clinical course associated, with diffuse peritoneal involvement resembling that of ovarian cancer, and it is also associated with deep myometrial invasion and lymphatic involvement (17). 
In a study investigating the pattern of metastasis and prognosis among clear cell carcinoma cases; Abeler et al. found that the 5 year survival decreases with myometrial invasion, which is one of the surgicopathologic risk factors. Five year survival was $90 \%$ for intramural tumor, while it was $15 \%$ in cases with deep myometrial invasion (3).

Xiaohai et al. investigated 310 patients retrospectively to determine the clinicopathological factors other than cell type affecting lymph node involvement (26). As a result of this study, it was found that the presence of LVSI, deep myometrial invasion and cervical invasion were determinants of lymph node involvement. This result is also supported by the results of another study. Fotopoulou et al. found that the presence of LVSI, grade, serous cell type and incomplete resection of the tumor were also associated with lymph node involvement (18). However, in our study there was no significant difference in depth of myometrial invasion, presence of LVSI and cervical metastasis between the aggressive cell type group and endometrioid cell type group. This means that aggressive cell type increases pelvic lymph node involvement independent of depth of myometrial invasion, presence of LVSI and cervical metastasis. Similarly, Goff et al. found in their study that extrauterine disease in uterine serous papillary carcinoma was not associated with depth of myometrial invasion and grade (7). Goff et al. investigated 50 cases of surgically staged uterine serous papillary carcinoma, and lymph node metastasis was observed in $36 \%$ of patients without myometrial invasion and $40 \%$ of patients with outer one-half myometrial invasion. Among 14 cases in which the tumor was limited to the endometrium, there was lymph node metastasis in 36\% and extrauterine disease was present in $43 \%$. In addition, Goff et al. found that the incidence of extrauterine disease was increased with the presence of LVSI (85\% of patients), but even if LVSI is not present in these patients, the incidence of extrauterine disease was still found to be high (58\% of patients). There are other studies which also reported that myometrial invasion had no prognostic value in uterine serous papillary carcinoma $(5,7,8)$.

In this study, ovarian and tubal involvement was found to be higher among the aggressive cell type group. This may explain the higher incidence of pelvic lymph node involvement in the presence of aggressive cell type. In contrast to this, although the adnexial involvement was increased with aggressive cell type, the para-aortic lymph node involvement was not increased with adnexial involvement with the aggressive cell type. Mariani et al. reported that one of the possible ways for para-aortic lymph node involvement in endometrial cancer was the peduncle of ovarian vessels. In their study, there was metastasis in the gonadal vein and surrounding soft tissue in $28 \%$ of patients with para-aortic lymph node involvement (27). Mc Meekin et al. also reported similar results and they found that the paraaortic lymph node involvement was present in 11 of 12 patients who have adnexial metastasis and/or positive peritoneal cytology (28). 240 cases of stage I-III endometrial cancer were surgically treated by total abdominal hysterectomy, bilateral salpingo-oophorectomy and retroperitoneal lymph node dissection. They investigated the histopathological factors from the prog- nostic aspect and found that the incidence of deep myometrial invasion, high nucleolar grade (G3), LVSI and pelvic lymph node involvement were higher among the serous papillary and clear cell carcinoma group compared to the endometrioid cell type group (29). In accordance with that study, we also found that pelvic lymph node involvement and adnexial metastasis was significantly higher among aggressive cell type cases.

For all stages in uterine serous papillary carcinoma, 5-year survival is found to be $30 \%(6,30)$. While 5 -year survival for stage I-II cases is $54 \%$ and $27 \%$ respectively, 5-year survival cannot be predicted in stage III-IV cases (31). Also, unfortunately disseminated disease and death is possible in th case of uterine serous papillary carcinoma even if the tumor is confined to the endometrium $(8,30,32)$.

As a result, in this retrospective study we found that the prognostic factors which determine the survival in the aggressive cell type group were poorer. Tubal and adnexial involvement in the aggressive cell type group were significantly higher. However, this situation was independent of depth of myometrial invasion, presence of cervical involvement and LVSI. Also, although it is not statistically significant, para-aortic lymph node involvement in the aggressive cell type group was approximately twice that in the endometrioid cell type group, and adnexial involvement was thought to be responsible for this. In the aggressive cell type group, the treatment plan should be as aggressive as the clinical course.

Since the number of patients included in this study was limited and the study was designed retrospectively, conclusions are restricted. In addition to this, the patients included in our study group were at high risk for lymph node metastasis. For that reason, well designed more prospective studies including all endometrial cancer patients are required for understanding of effect of cell type on variations in surgico-pathologic risk factors.

\section{Conflict of interest}

None declared.

\section{References}

1. Landis SH, Murray T, Bolden S, Wingo PA. Cancer statistics. CA Cancer J Clin 1999; 49: 8-31. [CrossRef]

2. Tropé C, Kristensen GB, Abeler VM. Best Pract Res Clin Obstet Gynaecol. 2001; 15: 433-46. Clear-cell and papillary serous cancer: treatment options. [CrossRef]

3. Abeler VM, Vergote IB, Kjorstad KE, Tropé CG. Clear cell carcinoma of the endometrium. Prognosis and metastatic pattern. Cancer 1996; 78: 1740-7. [CrossRef]

4. Christopherson WM, Alberhasky RC, Connelly PJ. Carcinoma of the endometrium: I. A clinicopathologic study of clear-cell carcinoma and secretory carcinoma. Cancer 1982; 49: 1511-23. [CrossRef]

5. Sherman ME, Bitterman P, Rosenshein NB, Delgado G, Kurman RJ. Uterine serous carcinoma. A morphologically diverse neoplasm with unifying clinicopathologic features. American Journal of Surgical Pathology 1992; 16: 600-10. [CrossRef]

6. Abeler VM, Kjorstad KE. Serous papillary carcinoma of the endometrium: a histopathological study of 22 cases. Gynecologic Oncology 1990; 39: 266-71. [CrossRef]

7. Goff BA, Kato D, Schmidt RA, Ek M, Ferry JA, Muntz HG et al Uterine papillary serous carcinoma: patterns of metastatic spread. Gynecol Oncol 1994; 54: 264-7. [CrossRef] 
8. Carcangui M, Chambers J. Uterine papillary serous carcinoma: a study of 108 cases with emphasis on the prognostic significance of associated endometrial carcinoma, absence of invasion, and concomitant ovarian carcinoma. Gynecol Oncol 1992; 47: 298 -305. [CrossRef]

9. Carcangiu M, Chambers J. Early pathologic stage clear cell carcinoma and uterine papillary serous carcinoma of the endometrium: comparison of clinicopathological features and survival. Int J Gyn Pathol 1995; 14: 30-8. [CrossRef]

10. Potish RA, Twiggs LB, Adcock LL, Prem KA. Role of whole abdominal radiation therapy in the management of endometrial cancer: Prognostic importance of factors indicating peritoneal metastases. Gynecol Oncol 1985; 21: 80-6. [CrossRef]

11. Gibbons S, Martinez A, Schray M. Adjuvant whole abdominopelvic irradiation for high-risk endometrial carcinoma. Int J Radiat Oncol Biol Phys 1991; 21: 1019 -25. [CrossRef]

12. Burke TW, Gershenson DM. Chemotherapy as adjuvant and salvage treatment in women with endometrial carcinoma. Clin Obstet Gynecol 1996; 39: 716-27. [CrossRef]

13. Pustilnik T, Burke TW. Adjuvant chemotherapy for high-risk endometrial cancer. Semin Radiat Oncol 2000; 10: 23-8. [CrossRef]

14. Craighead PS, Sait K, Stuart GC, Arthur K, Nation J, Duggan M et al. Management of aggressive histologic variants of endometrial carcinoma at the Tom Baker Cancer Centre between 1984 and 1994. Gynecol Oncol 2000; 77: 248-53. [CrossRef]

15. Levenback C, Burke TW, Silva E, Morris M, Gershenson DM, Kavanagh JJ et al. Uterine papillary serous carcinoma (UPSC) treated with cisplatin, doxorubicin, and cyclophosphamide (PAC). Gynecol Oncol 1992; 46: 317-21. [CrossRef]

16. Smith MR, Peters WA 3rd, Drescher CW. Cisplatin, doxorubicin hydrochloride, and cyclophosphamide followed by radiotherapy in high-risk endometrial carcinoma. Am J Obstet Gynecol 1994; 170: 1677-81.

17. Nordstrom B, Strang P, Lindgren A, Bergström R, Tribukait B. Endometrial carcinoma: the prognostic impact of papillary serous carcinoma (UPSC) in relation to nuclear grade, DNA ploidy and p53 expression. Anticancer Research 1996; 16: 899-904.

18. Fotopoulou C, Savvatis K, Kraetschell R, Schefold JC, Lichtenegger W, Sehouli J. Systematic pelvic and aortic lymphadenectomy in intermediate and high-risk endometrial cancer: lymph-node mapping and identification of predictive factors for lymph-node status. Eur J Obstet Gynecol Reprod Biol 2010; 149: 199-203. [CrossRef]

19. Schiller W. Mesonephroma ovarii. American Journal of Cancer 1939; 35: 1-21.
20. Scully RE, Barlow JF. `Mesonephroma' of ovary. Tumor of Mullerian nature related to the endometrioid carcinoma. Cancer 1967; 20: 1405-17. [CrossRef]

21. Kurman RJ, Scully RE. Clear cell carcinoma of the endometrium: an analysis of 21 cases. Cancer 1976; 37: 872-82. [CrossRef]

22. Hendrickson M, Ross J, Eifel P, Martinez A, Kempson R. Uterine papillary serous carcinoma: a highly malignant form of endometrial adenocarcinoma. American Journal of Surgical Pathology 1982; 6: 93-108. [CrossRef]

23. Moll UM, Chalas E, Auguste M, Meaney D, Chumas J. Uterine papillary serous carcinoma evolves via a p53-driven pathway. Human Pathology 1996; 27: 1295-300. [CrossRef]

24. Reinartz JJ, George E, Lindgren BR, Niehans GA. Expression of p53, transforming growth factor alpha, epidermalgrowth factor receptor, and c-erbB-2 in endometrial carcinoma and correlation with survival and known predictors of survival. Human Pathology 1994; 25: 1075-83. [CrossRef]

25. Sherman ME, Bur ME, Kurman RJ. p53 in endometrial cancer and its putative precursors: evidence for diverse pathways of tumorigenesis. Human Pathology 1995; 26: 1268-74. [CrossRef]

26. Xiaohai T, Kenjiro T, Weimin Y, Kazuo O, Ryuichiro T et al. Clinicopathological Factors Predicting Retroperitoneal Lymph Node Metastasis and Survival in Endometrial Cancer. Jpn J Clin Oncol. 1998; 28: 673-8. [CrossRef]

27. Mariani A, Dowdy SC, Cliby WA, Gostout BS, Jones MB, Wilson TO et al. Prospective assessment of lymphatic dissemination in endometrial cancer: A paradigm shift in surgical staging. Gynecol Oncol 2008; 109: 11-8. [CrossRef]

28. McMeekin DS, Lashbrook D, Gold M, Scribner DR, Kamelle S, Tillmanns TD et al. Distrubition and its significance in FIGO stage IIIC endometrial cancer. Gynecol Oncol 2001; 82: 375-9. [CrossRef]

29. Sakuragi N, Hareyama H, Todo Y, Yamada H, Yamamoto R, Fujino $\mathrm{T}$ et al. Prognostic significance of serous and clear cell adenocarcinoma in surgically staged endometrial carcinoma. Acta Obstet Gynecol Scand. 2000; 79: 311-6. [CrossRef]

30. Kato DT, Ferry JA, Goodman A, Sullinger J, Scully RE, Goff BA et al. Uterine papillary serous carcinoma (UPSC): A clinicopathologic study of 30 cases. Gynecologic Oncology 1995; 59: 384-9. [CrossRef]

31. Christopherson WM, Alberhasky RC, Connelly PJ. Carcinoma of the endometrium. II. Papillary adenocarcinoma: a clinical pathological study, 46 cases. American Journal of Clinical Pathology 1982; 77: 534-40.

32. Silva EG, Jenkins R. Serous carcinoma in endometrial polyps. Modern Pathology 1990; 3: 120-12. 